\title{
A LIBERDADE DO AMOR EM S. AGOSTINHO E KIERKEGAARD
}

\author{
The freedom of love in S. Augustin and Kierkegaard
}

Arciane Carvalho ${ }^{1}$

RESUMO: São notórios os diversos pensamentos sobre o amor e sua inquietude pela liberdade, estes, são sentimentos expostos pelos seres humanos como requisitos para encontrar a felicidade. Essa busca se dá pelo anseio de encontrar-se algo que possa trazer o estado pleno de satisfação, com isso exploramos as visões de S. Agostinho e Kierkegaard que estabelecem uma grande relação na questão de que Deus é o motivo principal para o real encontro de liberdade e amor estabelecidos nos homens. Que por serem confundidos por seus princípios ilusórios acabaram se distanciando do verdadeiro sentido de se está em plena felicidade que é aquela encontrada em Deus, quando o homem escolhe Servi-lo e abandonar os prazeres mundanos.

PALAVRAS-CHAVE: Amor; Liberdade; Deus.

\begin{abstract}
Are notorious various thoughts about love and concern for freedom , these are
\end{abstract} feelings exposed by humans as requirements to find happiness. This quest is given by the desire to find yourself something that can bring the full state of satisfaction, we explored the views of St. Augustine and Kierkegaard that establish a great relationship in question that God is the main reason for the actual meeting freedom and love established in men. But they're confused by his illusive principles ended up distancing the true meaning of it is in full happiness is that found in God when man chooses to serve him and give up worldly pleasures.

KEYWORDS: Love; Freedom; God.

\section{Uma visão de Liberdade em Agostinho}

Santo Agostinho procura esclarecer várias questões de sua filosofia, tendo como um dos assuntos, a liberdade, que é tida como uma forma de expressividade para a alma do ser humano. O seu testemunho mostra as claras mudanças ocorridas e a sua nova perspectiva de vida. ${ }^{2}$

\footnotetext{
${ }^{1}$ Graduanda em Filosofia pela CEAD-UFPI.

2 Ao ouvir a história de vida do Santo Antão do Deserto pro Placiano e seus amigos em um verão de 386, Agostinho se converte, além de sua conversão ele conta que sua passagem ao cristianismo foi estimulado por uma voz de infantil que pedia-lhe para 'tomar e ler' (em latim: tolle, lege), com isso compreendeu que aquele acontecimento foi algo do comando Divino para ter ação de parar com tudo o que rodeava e abrir a Bíblia e ler a primeira coisa que encontrasse. Agostinho ao abrir a Epistola é transformado pelo trecho encontrado na epístola aos Romanos, Capítulos 12 ao 15, onde o apostolo Paulo descreve como o Evangelho pode transformar o ser humano e seu comportamento. A partir dessa conversão Agostinho passa a ter uma nova vida, fora dos prazeres mundanos e dedicado às coisas de Deus.
} 
Suas teses giram em torno de questões essenciais para a formação do homem em um ser melhor. Pode-se observar isso, em suas obras, como por exemplo, as Confissões (escrita provavelmente em 397 d.C.) livro que discorre sobre a busca da verdade, tendo como exemplo principal o seu "errar" anterior ao da descoberta de Deus, os seus novos caminhos de uma vida de libertinagem, sobre o verdadeiro bem.

Uma das questões que foram bem expostas por Agostinho foi a sua reflexão sobre a liberdade e a sua relação com o livre-arbítrio e a graça, além de ressaltar ainda questões sobre o pecado original. Na linguagem popular, liberdade é uma expressividade de uma pessoa independente, pois através da independência encontram-se estruturas para agir por mérito ou não, próprio. Em uma linguagem culta, os dicionários informam que liberdade é algo como o estado de pessoa livre e isenta de restrição externa ou coação física ou moral. E para Agostinho do que se trata a liberdade?

Em seu livro as Confissões, ele deixa claro que só podemos adquirir a liberdade quando nos distanciássemos do pecado, pois alcançar a liberdade seria um mérito de possuir felicidade. Com isso entra a questão de escolha, que implica a determinação, pois é a partir da firmeza de algo que resulta as escolhas. Tendo como referência os diários do filósofo Kierkegaard encontramos algo de valor imenso, como:

Agostinho e muitos modernos têm mostrado que é uma ilusão conceber abstratamente livre esse liberum arbitrium segundo o critério; como se um homem em todos os momentos de sua vida deve ser imediatamente fornecido com esta possibilidade abstrata, [...] como se a liberdade não fosse ao mesmo tempo um estado histórico. (KIERKEGAARD, 1993, p. 331).

É preciso compreender que a questão da liberdade é fundamental ao interesse humano, pois todo ser humano almeja ser livre e deliberar suas próprias decisões. Agostinho não trata da liberdade como desejo de desprender-se dos domínios, ou seja, livrar-se dos homens, cidade, posses, falsas honras e do dinheiro, ele esclarece que os domínios são guiados por uma lei temporal nas quais muitos procuram alcançar.

A liberdade de escolha significa um ato de possibilidades para diversas formas de bem, pois é através dessa subjetividade humana que consiste a incessante busca. Em uma forma mais simples, a liberdade constitui duas alternativas entre duas possibilidades, sim ou não, (bem ou mal). Essa possiblidade traz a satisfação de uma e exclui a outra. Segundo Santo Agostinho, a liberdade interior é algo imenso, maior do que qualquer bem exterior, sendo eles adquiridos por coisas externas, coisas inconstantes, como, o dinheiro, fama, bens materiais, entre outros, mas o que conta são todos aqueles bens adquiridos interiormente, como a paz, o amor e a felicidade que são sentimentos constantes que trazem consolidação para a alma. 
É muito interessante à questão da liberdade no contexto humano. O homem é um ser racional repleto de defeitos, qualidades, desejos, especulações, pensamentos e limites, além de ser um sonhador. Humanamente, os nossos "sentimentos" influenciam muito na nossa formação, sentimentos esses de amor, paz, desejo, felicidade. Contudo, poucos retomam suas vidas em um contexto individual, por mais que a própria opinião que vale, consequentemente, somos guiados por incertezas, pois nossa capacidade nos confronta a um aglomerado de anseios. Por desejarmos tanto as coisas de um jeito único, somos presos muitas vezes em uma mesma vida rotineira. Por isso, Agostinho deixa bem claro que o mal contamina a alma ao pecado, o que implica dizer que as nossas maiores incertezas nos leva a um estado onde o bem e o mal estão frente a frente e logo somos levados pelo mais atrativo. Digo isso, pois, no ditado popular da lógica humana, os caminhos mais curtos levam a resultados ruins e os mais longos nos colocam em um patamar surpreendente, logo um resultado bom.

A verdadeira liberdade dita por Santo Agostinho é aceitar a graça de Deus. A opção de escolha (livre-arbítrio) não é uma total liberdade. O livre-arbítrio nos concede grandes possibilidades de escolher o bem (Deus) ou não, mas a alma só será realmente livre por meio da ajuda divina, optando por seguir a vontade de Deus, se livrando dos bens e passando a desejar as coisas do alto, as coisas do Criador. No evangelho de João capítulo 8:31-32, Jesus deixa uma mensagem bem clara para seu povo e aos judeus que haviam crido nele: "Se vocês permanecerem firmes na minha palavra, verdadeiramente serão meus discípulos. E conhecerão a verdade, e a verdade os libertará".

Para Agostinho, o mundo criado por Deus é uma obra perfeita, pois Deus na sua infinita bondade revela de maneira esplendorosa tudo aquilo que é necessariamente bom, implica a ideia do ser. Com isso percebemos que Deus criou o bem e através desse bem divino possuímos a total escolha de liberdade ou prisão.

\section{1 - Liberdade e Livre-Arbítrio em Agostinho}

O ser humano regrediu em uma caminhada inconstante. Chegamos a um limite final, a um limite que interfere o nosso procedimento futuro, pois estamos presos nas mesmas opiniões, presos numa mesma sequência de fatos. Por mais que o Céu seja o limite, nossas atitudes reagem contrariamente a uma prisão. As nossas escolhas definem até onde podemos chegar, para Agostinho o livre- arbítrio é a atitude de escolha que nos dá direito e não a liberdade, liberdade essa que define um bem ou um mal.

O termo "livre-arbítrio" na etimologia latina significa 'livre decisão’ e para Agostinho é um dom de Deus, enviado a todos os homens e que os permite agir livremente de acordo com a 
sua vontade. Na concepção de Agostinho, a liberdade exibiu uma opção do ser humano de escolher o seu caminho, cujos critérios de escolha estão delimitados por uma ordem exterior, a qual estabelece o "bem" e o "mal" de cada opção. Em seu livro, O Livre- Arbítrio, Santo Agostinho explica que o mal é a ausência de Deus (Cf. AGOSTINHO, Santo. 1995. p.142-3), essa ausência acontece pela escolha de opção do ser humano em caminhar por caminhos que o distancie do bem, sendo que o mal não pode vir de Deus.

Diante de tantas indagações, podemos instituir uma pergunta: Como algo criado por Deus pode ser um mal? Em Seu Livro as Confissões, Agostinho defende que Deus é o criador do bem. Então, pode-se afirmar que não há possibilidades do Criador haver criado o mal, pois o livre-arbítrio se torna causa do mal, não por culpa de Deus, mas por meio daqueles que o receberam e não usaram devidamente, atribuindo assim, o mal. Por isso, para Santo Agostinho:

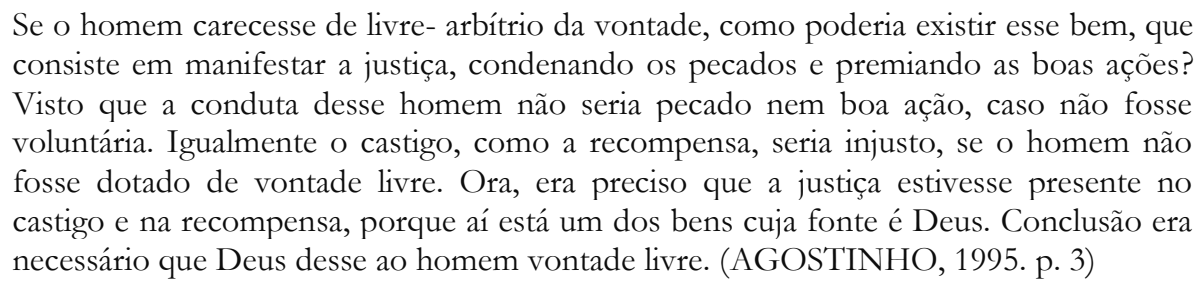

Com isso Agostinho afirma que Deus não é o autor do mal, mas sim, o homem, e podese dizer que não existe só um autor, mas todo aquele que toma alguma atitude má é classificado como tal. A maldade não se torna inata, de alguma forma aprendemos a ser maus, isto é, o mal teria se proliferado ao mundo de pessoa para pessoa sucessivamente. Todavia, de acordo com S. AGOSTINHO (1995, p. 26), isso não poderia acontecer, visto que, o mal nem pode ser ensinado e nem pode ser aprendido, pois, "mostra-se evidente é que a instrução sempre é um bem, visto que tal termo deriva do verbo "instruir", assim, será impossível o mal ser objeto de instrução. Portanto, o mal não é passado de pessoa para pessoa, mas sim, encontra-se em cada um independentemente do outro.

Com isso percebemos que Santo Agostinho diferencia o significado de liberdade com o de livre-arbítrio. Ele mostra em seus pensamentos que a liberdade em relação ao ser humano é o afastamento do pecado e passando a viver na graça divina, em oposição a uma escravidão, que se indica pelo atendimento das paixões. E o livre-arbítrio significa a liberdade por sua perfeição, pois é da sua atividade que o ser humano pode escolher uma vida reta (bem) ou pecaminosa (mal).

Podemos ressaltar que para Agostinho, quando o ser humano opta por escolher o mal (atitude de escolha dada pelo "o livre-arbítrio"), o homem não possui mais o poder de livre escolha e muito menos de liberdade, pois sua alma está contaminada pelo pecado e só poderia se 
redimir se houvesse o arrependimento e o homem deixasse os prazeres e optasse pela graça divina.

A lei eterna significa a razão suprema (Nous), esta que é necessária obedecer sempre e logo através dela os seres humanos bons conquistam a vida feliz (Felicidade), e os maus, a infelicidade (Infortúnio), (Cf. AGOSTINHO, 1995, p. 41). É a razão suprema que ordena o ser humano que se desligue do afeto pelas coisas passageiras e se volte para as coisas eternas, pois elas conduzem a verdadeira felicidade. Diante dessa razão suprema, a lei primordial, eterna, é a verdade e essa verdade consiste na liberdade. Santo Agostinho diz: "A nossa liberdade consiste em estar submetido à Verdade. Essa Verdade é o nosso Deus mesmo, o qual nos liberta da morte, isto é, da condição do pecado" (Cf. AGOSTINHO, 1995, p. 121).

\subsection{O problema dogmático do pecado original}

Com base em algumas leituras de obras filosóficas, é nítida a clareza de assuntos referentes ao Criador (Deus) e consequentemente a expressividade desse tema gera grandes indagações que giram em torno do assunto, como por exemplo, o pecado original, que é decorrente na filosofia de Agostinho. Com isso podemos estabelecer a criação de uma 'ponte' entre ele e outro grande filósofo que fala sobre o assunto, como Kierkegaard.

Consequentemente quando ouvimos a palavra "pecado" logo entendemos que é algo relacionado ao mal. Agostinho defendia a doutrina do pecado original, porque para ele o homem tinha cedido ao pecado, como consequência a natureza humana e dessa forma, foi contaminada por um mal obscuro. Sendo assim, a ajuda de Deus era indispensável, insubstituível, ou seja, sem Ele era impossível, somente pelo o livre-arbítrio, vencer as circunstâncias da vida. E para livrar-se desse mal era preciso à ajuda divina para escolher o certo ou retorna a Deus por Sua graça, a qual Santo Agostinho define como "um poder interno e secreto, maravilhoso e inefável" que é operado por Deus nos corações dos homens. (Cf. COUTO, 2014).

Mas de onde surge esse mal? No livro de Gênesis 1.27 encontra-se essa mensagem: "Deus, portanto, criou os seres humanos à sua imagem e semelhança: macho e fêmea". Nasce Adão e Eva que como diz a história viviam no paraíso, e Deus apresentando-se a eles, ordenou que de todos os frutos pudessem comer, menos do fruto da árvore que estava no meio. Diante disso, Eva iludida pela serpente conduz Adão e juntos comem o fruto e dali percebem que estavam nus. Assim, surge o primeiro ato de pecado, o primeiro ato de escolhas influenciadas que gerou um grande erro. 
Santo Agostinho compartilhava a ideia que Deus é o bem, e que tudo que Ele criou é bom, como por exemplo, o homem, que gozava da plena perfeição e liberdade, vergável ao bem e ao mal, antes do pecado.

\begin{abstract}
Mas a atual natureza, com a qual todos vêm ao mundo como descendentes de Adão, tem agora necessidade de médico devido a não gozar de saúde. O sumo Deus é criador e autor de todos os bens que ela possui em sua constituição: vida, sentidos e inteligência. $\mathrm{O}$ vício, no entanto, que cobre de trevas e enfraquece os bens naturais, a ponto de necessitar de iluminação e de cura, não foi perpetrado pelo seu Criador, ao qual não cabe culpa alguma. Sua fonte é o pecado original que foi cometido por livre vontade do homem. Por isso, a natureza sujeita ao castigo atrai com justiça a condenação. (AGOSTINHO, 1995, p. 115)
\end{abstract}

Para Agostinho o pecado nasce depois da atitude de Adão "Por meio de um só homem o pecado entrou no mundo e, pelo pecado, a morte; e assim a morte passou a todos os homens, porque todos pecaram.” (Rm 5,12). ${ }^{1}$

Dessa forma, o pecado é transmitido á toda criatura atrativamente. Nesse sentido, observa-se o estado da natureza, doente, precisando assim, urgentemente de um médico para curar a saúde, e este remédio não se situa no próprio homem. Assim, Agostinho diz que a liberdade só podia ser uma omissão de um processo de cura. E somente Deus com a sua divina graça faria essa cura milagrosa.

Podemos dizer que para Agostinho o pecado é algo do mal, trazido pela consequência do ato de Adão e Eva. Com isso podemos ressaltar ainda uma questão do livre-arbítrio, pois a atitude de Adão e Eva não foi algo que Deus ordenou, porém partiu de uma influencia da escolha e do desejo deles próprios. Dessa forma podemos dizer que Deus avisou que de todos os frutos poderiam comer, menos daquela árvore, testando assim o ato da obediência e do ouvir a voz de Deus. Santo Agostinho via em Deus a liberdade de uma vida de pecado, e acreditava na Sua infinita bondade.

O pecado original, consequentemente o mal, é algo prejudicador ao homem, pois ele coloca o ser humano no "fundo do poço", onde a liberdade nunca será tida. É necessário temer tudo aquilo que há desconfiança do pecado. Assim, surge a pergunta: "Como afastar o mal"?

Agostinho em seu livro, as Confissões, pronuncia novamente que libertar-se do mal é desfrutar de uma vida com o Criador, logo, Deus. Quando o indivíduo passa a ter essa vida de compromisso com o Criador e afasta o mal de sua vida.

Com isso, entra a angústia sendo o estado do ser eminente e inevitável, ou seja, como uma origem exclusivamente interna. Nesse estado a angústia está ligada ao vazio e o sujeito é somente uma possibilidade, ainda sem determinação. A angústia se torna um fato extremamente

\footnotetext{
${ }^{1} \mathrm{O}$ fato do pecado estar ligada a Adão é justamente o fato que traz a necessidade espiritual da vinda de Cristo, e essa justificativa foi utilizada contra os pelagianos.
} 
imutável à liberdade, pois ela toma o conceito de prisão pra si e se sobressai, porque é nela que os sentimentos humanos se encontram totalmente frustrados e perdidos. Nota-se que Santo Agostinho vê a angústia ${ }^{1}$ como sentimentos sufocadores para a alma humana, é onde o indivíduo se encontra no fundo do poço, pois seus sentimentos estão a um nível peculiar de tristeza causada por um mal.

Diante disso, entra o filósofo dinamarquês do Séc. XIX, Kierkegaard, vindo de uma tradição protestante que também pensou no problema do mal, principalmente na obra, $O$ conceito de angústia. Kierkegaard redefine o conceito de angústia sendo: "uma determinação do espírito sonhador (...) é a realidade da liberdade como puro possível” (KIERKEGAARD, 2010, p. 45). A partir dessa redefinição, ele inicia sua análise de angústia e mal por meio da queda de Adão e Eva, assim como Agostinho, que demonstrou nessa passagem bíblica que a queda desses dois personagens se propiciou através da possibilidade de escolher, no sentido de que a existência humana é definida por uma decisão, uma escolha, ou seja, não são determinados pela natureza, mas sim pelo próprio eu individual.

A reflexão filosófica de Kierkegaard demonstra a própria luta interior, luta de quem pode sentir a dor da vida e de quem pode enfrentá-la. Kierkegaard assumiu a angústia como uma etapa para construir uma existência autêntica, sua proposta era encontrar na angústia um salto para a fé, aonde o homem chegaria ao nível de estágio estético e ético. Assim, somente através do seu estágio religioso é que o ser humano poderia assumir sua peculiaridade de solidão a Deus, assim, assumiria a sua finitude a um desejo de infinito.

Kierkegaard, acreditava que o salto para a fé nos aproximaria de Deus, logo essa seria uma das soluções. Kierkegaard na obra intitulada Temor e tremor, elogia Abraão, via nele o personagem do "cavaleiro da fé", pois Abraão foi o maior exemplo de fé e obediência a Deus. Conhecendo a história de Abraão, pode-se afirma que por seu ato extremo de fé e obediência a voz de Deus, ele foi um homem bem sucedido, liberto das ciladas do pecado e como Deus disse a ele: "[...] a sua descendência será grande e abençoada (Gênesis 26.4-5)".

Não foi por via da fé que Abraão abdicou Isaac, mas foi por via da fé que Abraão recebeu Isaac [...] a fé é um paradoxo monstruoso num ato santo e agradável a Deus, um paradoxo que devolve Isaac a Abraão, um paradoxo qual nenhum pensamento pode apropriar-se porque a fé começa precisamente onde o pensamento acaba. (KIERKEGAARD, 2008, p.105).

Assim, para Kierkegaard, o salto da fé dado pelo cavaleiro da fé (Abraão) é o maior de toda fé, e, através dessa fé, o homem passa a viver uma vida na finitude. Podemos dizer que a fé

\footnotetext{
1 Agostinho, via na angústia um estado de decadência humana, em seu livro as Confissões, ele explica que o homem se lança em um mundo de maneira que nunca está satisfeito com o que vive ou deixa de viver, com o que tem ou deixa de ter. Por esse fato vive nas margens de uma angústia que só acabaria quando encontrasse a verdadeira felicidade, logo Deus.
} 
destacada por Kierkegaard compromete o homem a crer e obedecer a Deus, logo se distanciando do pecado e possuindo assim uma vida de liberdade, pois o "saltar" para fé é um movimento necessário e que pode ser a tentativa de vencer a queda inerente do pecado.

Por conseguinte, segundo Agostinho, afastar-se do pecado seria escolher a Deus ou os bens superiores, escolher a possibilidade da graça divina, pois a vontade de ser livre fundada pela graça divina refere-se como uma faculdade que o indivíduo situa-se no mundo exterior, porém quando escolhe a Deus, impregna uma fé que efetua um retorno de si mesmo.

É licito que Agostinho defensor do carácter mediador da Igreja e dos sacramentos, vê no homem um indivíduo capaz de ser guiado pela vontade de Deus e quando isso acontece inaugura uma completa rotura (na linguagem kierkegaardiana: um salto) que o sobrepõe em um nível de fé e amor, distante do mal, distante do pecado. Poderíamos Afirma que segundo Agostinho, o amor ao Deus Único, afastasse definitivamente o mal da vida do homem, inerente desse mal existir, o homem estaria seguro e firme no amor de Deus. A ideia do pecado (mal) propicia no homem a atitude de escolha, por consequência ele cai no erro de pecar e com isso afasta-se de Deus, das coisas verdadeiras que ele pode oferecer.

Portanto, o pecado original influenciou o homem ao ato de errar, induzido pelas necessidades e desejos pecaminosos. Porém, pelos relatos estudados, compreendemos que Agostinho e Kierkegaard criaram um ponto nas suas teorias em que a fé e a renúncia seriam atitudes necessárias para libertar-se de uma vida pecaminosa e passasse a possuir uma vida feliz pela graça divina de Deus.

\subsection{Liberdade e graça em Agostinho}

Questionar as questões humanas é algo muitas vezes indiscutível pelo fato de não conhecermos os pensamentos do homem. Embora existam estudos profundos, ninguém conhece perfeitamente a ninguém a não ser Deus. Dessa forma, não se sabe até onde as nossas escolhas reagem de forma harmoniosa ou não, o fato é que Deus sabe, porém o livre-arbítrio é mérito de escolha própria e somente as nossas escolhas podem nos levar aos caminhos bons, da verdade que nos leva a vivermos felizes livremente ou nos conduz aos caminhos ruins que nos aprisiona ao mal.

Santo Agostinho no seu livro, o livre-arbítrio, em um diálogo com Evódio relaciona a vontade dos homens com a felicidade:

Por qual motivo, então, nem todos eles a obtêm? Porque, como nós dissemos e concordamos, é voluntariamente que os homens a merecem. E acontece que voluntariamente também chegam a uma vida de infortúnios. E, assim, recebem o que merecem [...]. É porque, ao afirmarmos que os homens são voluntariamente infelizes, não dizemos [...] que eles queiram ser infelizes, mas que possuem tal vontade, que a 
desgraça se segue necessariamente, mesmo contra o desejo de felicidade. [...] todos querem ser felizes, mas sem poder sê-lo. (AGOSTINHO, 1995, p. 14).

Para Agostinho, o famoso ditado popular “querer é poder" não é válido. Ao falarmos de felicidade, ele visa que o ser humano tem justa escolha, ou seja, tem liberdade em desejar coisas para si próprias, mas só o desejo não basta. Há a necessidade de desapego, tal desapego que nos prende aos bens terrenos e somente seremos felizes quando nos libertamos dos tais e assim poderemos usufruir de uma vida de liberdade.

Mas existe também a possibilidade de perda da liberdade do homem, isso consequentemente acontece por conta do pecado. O ser humano é invadido por suas vontades e escolhem caminhos contrários ao do bem, em consequência de uma forma "irônica", o ser humano torna-se escravo do seu próprio eu. Para Agostinho, o pecado é livre, até certo sentido, mas ao mesmo tempo é uma sob sugestão. Isso implica que o ser humano é livre para escolher, porém, suas más escolhas permeiam seus maus desejos.

Consideremos as seguintes observações feitas por Philip Schaff em relação a o pensamento agostiniano a respeito da liberdade:

\begin{abstract}
Por liberdade, Agostinho entende, em primeiro lugar, simplesmente espontaneidade ou automatização, porquanto oposta à ação sob coação ou por instinto animal. Tanto o pecado quanto a santidade são voluntários,isto é, atos da vontade, não moções da necessidade natural. Essa liberdade pertence em todos os tempos e essencialmente à vontade humana, mesmo no estado pecaminoso (no qual a vontade humana é, estritamente falando, voluntariosa); ela é a condição necessária da culpa e do castigo, do mérito e da recompensa. Nessa visão, nenhum homem pode negar a liberdade sem destruir a responsabilidade e a natureza moral do homem. Uma vontade involuntária é uma autocontradição tão exposta quanto uma inteligência ininteligente. (SCHAFF, 2001, p. 62).
\end{abstract}

Percebemos que nessa breve observação de Philip Schaff, ele usa o termo "automatização" como ações humanas da qual proporciona uma coerção externa no ser humano. Isso acontece por uma condição necessária ou simplesmente um pré-requisito para um comportamento ser classificado moralmente. Portanto, a essa "automatização" pode ser levada para o bem ou mal. A resposta de Agostinho afirma essa possibilidade: De onde vem praticarmos o mal? Se não me engano, tal como a nossa argumentação mostrou, o mal moral tem origem no livre-arbítrio de nossa vontade (Cf. AGOSTINHO. 1995, pág. 16) .

Com isso, o termo livre-arbítrio é utilizado por Agostinho para reconhecer uma característica relativa ao ser humano em determinado tempo, seja ele antes ou depois do pecado original. Diante disso, podemos confirmar que o livre-arbítrio não corresponde a um mal em si, mas um bem, uma possibilidade dada por Deus ao ser humano, que o se torna moralmente responsável por suas escolhas. 
O ser humano evidência diversos momentos, tais eles que dependem da sua capacidade e necessidade. É licito que o livre-arbítrio é um mérito para alcançar a liberdade, mas essa tal liberdade pode nos levar a dois caminhos, o bem e o mal. Diante dessa perspectiva observamos que o que leva o homem ao pecado é a suas necessidades, pois nem sempre elas possuem desejos proveitosos. O termo "necessidade" está relacionado com a natureza e suas leis, como por exemplo: o sol, ele aparece para iluminar o dia, ou seja, trazer clareza. Quando uma plantação se inicia, logo ela precisa do sol para seu crescimento, porém se não houver chuva aquele sol destruirá toda a plantação que irá murchar. Porém sabemos que o sol não é moralmente responsável, pois seu ciclo permeia fatores que não o possibilita de aparecer ou não. Então, existe a necessidade do sol, mas não a sua liberdade.

Logo, observamos que essa "necessidade", causa uma tensão moral que se refere ao mal em ações de criaturas volitivas. Santo Agostinho classificava o homem como um ser "caído", pecador, porém não negava sua função moral. Com isso podemos dizer que essa "queda" tem um papel auxiliador quando se relaciona ao pecado original. Levando o pensamento agostiano podemos dizer que somente Deus é livre, pois sua existência não está condicionada pela natureza, ou seja, em Deus não existe necessidades.

Assim, a "queda" do ser humano pelo pecado é passo para um nível inferior dos bens temporários, os quais transformam na fonte de prazer ou desejo como elemento essencial para a vontade do pecado. Diante disso, a necessidade é tida como caída nos momentos das escolhas, pois opõe-se à liberdade, e somente o retorno para Deus poderia "cicatrizar as feridas". Esse retorno se dá pelo desligamento das coisas matérias em favor das coisas divinas, e esse é o princípio operativo de Deus chamado de "graça".

Dessa forma percebemos que a liberdade do homem se danifica e só pode se restaurar por meio da divina graça. E essa graça passa a ser buscada pelo ser humano, pois só ela traz a particularidade com Deus e através dela encontra-se a possibilidade de mudanças espirituais. Ainda que o ser humano esteja vivo fisicamente, por consequência suas ações e suas tomadas de decisões causa sua morte espiritual, pois sua mente deriva de vontades ligadas ao pecado original. Assim, qualquer espírito pode conhecer e amar o bem, pois o verdadeiro conhecimento e amor é aquele influenciado pelo Ser divino, que pela graça proporciona na mente e na vontade um esclarecimento da verdade e faz com que ela deseje o se preencher de coisas agradáveis, amáveis, eternas que é Deus.

A graça divina é o antecessor da fé no sentido assistencial, pois ela ajuda o ser humano a viver dignamente. É interessante o modo como Agostinho vê o ser humano, pois acredita na 
capacidade moral de cada pessoa. No livro, Sobre a Graça e o Livre-Arbitrio, podemos concluir o sentido de liberdade e graça na visão de Santo Agostinho, em esclarecimento ele diz:

[...] A liberdade não é, a rigor, o poder de escolha: é o amor ao bem, é o estado da vontade orientada para o bem, que é Deus. Inscrever-se no movimento que conduz o homem, segundo sua vocação a participar da vida divina. Essa liberdade não pode existir senão na graça: Deus é sempre o primeiro a amar e a dar. "Deus sustenta sua existência no ser". Se o homem contradiz essa orientação, perde essa liberdade. Mantém, porém, se livre-arbítrio. (AGOSTINHO, 1999, p. 105).

Observando esse trecho podemos identificar a diferença entre liberdade e livre-arbítrio e a relação entre liberdade e graça. Em seu livro: A Graça, Santo Agostinho procura esclarecer a questão da relação do homem com Deus, por meio da caridade derramada em seu coração. Essa graça é que o homem alcance em Deus a felicidade necessária para se desprender dos desejos mundanos e estar diretamente ligadas as coisas Divinas que certamente irá proporcionar alicerces fortes, verdadeiros e eternos, aos quais levará o ser humano a se liberta da conduta igualitária de escolhas erradas e se conduzir para os caminhos do bem que levara a total liberdade.

Assim, percebemos que a liberdade, na visão de Agostinho, é tida como uma atitude individual, não implicando dizer que a questão do livre-arbítrio seja total responsável por nossa escolha, mas informa que somos responsáveis por nossos próprios atos, e se escolhemos um caminho que nos leve a algum mal a culpa não é dada a Deus, mas ao nosso próprio ser que nos conduz a um resultado negativo. Podemos salientar também que essa liberdade traz grandes resultados, pois a liberdade é encontrada quando o ser humano se integra a graça divina, essa graça que é Deus. Sabemos que Agostinho via em Deus a fonte da felicidade, assim, quando se encontra a liberdade, se está na verdade, se encontra com Deus e possuía a felicidade.

\section{O Amor como pleno cumprimento á lei}

A perspectiva do amor ilustra a trajetória da vida de qualquer pessoa. O amor é como um anseio de pureza de um sentimento mútuo que esteja interligado por uma eternidade. O amor é motivação a qualquer indispensabilidade de cuidados que envolvem diferentes formas, como, amor materno ou paterno, amor fraterno, amor físico, amor platônico, amor à vida, amor pela natureza, amor pelos animais, amor altruísta, amor próprio, e etc. Enfim, falar de amor envolve várias questões, tais, incorporam etapas para chegar a um resultado positivo de total felicidade.

Santo Agostinho procura mais uma vez esclarecer questões que circulam no ciclo de vida humana, como o amor. Esse amor não carnalmente, mas o amor espiritual que direciona o ser humano a adquirir maturidade para se relacionar com o meio, as pessoas e o Criador. Ele procura 
compreender sobre a melhor forma de conduzir o homem ao caminho que deve seguir, proporcionando uma ética que seja harmonizadora com os preceitos morais cristãos.

Na obra, O conceito de amor em Santo Agostinho (tese defendida em 1929), escrito por Hannah Arendt, o filósofo é ressaltado na maneira que amar não é outra coisa se não anelar ${ }^{1}$ algo por si mesmo, ou seja, o anelo é ligado como objeto determinado. Logo, algo que se busca por coisas que conhecemos e assim estabelece na alma o sentimento de segurança. Assim, podemos estabelecer que o amor seja um anelo que determina e liberta o homem do temor, pois a insegurança que é ressaltada nos corações humanos concede o sentimento de fracasso, angústia logo desistência de alcançar o seus ideais. Mas com o sentimento trazido pelo amor, exclui-se toda possibilidade de medo e encaixa-se o homem a um nível de maturidade, em que ele é capaz de distinguir o verdadeiro amor que é vindo de Deus e buscar cumprir com todos os requisitos para estar sempre interligado nesse divino amor.

Em outras palavras, podemos dizer que o amor para Santo Agostinho expressa a divindade do amor de Deus, onde nós somos exalados por esse amor desde a criação do mundo, e criamos um relacionamento com Ele e com o nosso semelhante, e logo podemos classificar isso como o cumprimento de uma lei. Mas qual lei? A lei da verdade, ensinada por Deus a respeito do verdadeiro amor: "Amar a Deus sobre todas as coisas e ao próximo como a si mesmo" (Marcos 12.31-32).

Nesse sentido, consideramos que Kierkegaard possa enriquecer essa investigação. Após haver investigado a temática do amor na sua tese, O conceito de amor em Santo Agostinho. Arendt, já ciente também da leitura kierkegaardiana sobre o amor, avalia a bondade e como essa se configura como contraposta aquilo que a antiguidade clássica compreendia como útil ou excelente.” (PAULA, 2010, p. 85).

\footnotetext{
Mas o amor cristão, que é o pleno cumprimento da leí, está presente justamente, Integro e concentrado, em cada urna de suas manifestações: e, contudo ele é puro agir; ele está, portanto, igualmente afastado tanto da inatividade quanto da agitação febril. Jamais ele assume algo antes da hora e faz urna promessa em lugar da ação; jamais se satisfaz consigo mesmo na ilusão de já estar pronto; jamais se demora junto a si mesmo deliciando-se consigo; jamais fica sentado por aí ociosamente espantado de si mesmo. Ele não é aquele sentimento escondido, ocultamente enigmático por trás das grades do inexplicável, que o poeta quer atrair para a janela; não é um estado de ânimo na alma, que mimado desconhece qualquer leí, nem quer conhecer, ou quer ter para si a sua própria lei e só quer escutar canções: ele é puro agir, e cada urna de suas ações é sagrada, pois ele é o pleno cumprimento da lei. (KIERKEGAARD, 2005, p. 122).
}

\footnotetext{
1 O termo "anelar" significa desejar algo com ansiedade, aspirar. Implica dizer que o homem busca a verdadeira felicidade e está, para Agostinho, tem origem no amor, o homem feliz possui amor em seu coração, estando a sua raiz em Deus, ou seja, o seu anelo se fixa pela ansiedade de Deus que é o ser determinante para a busca continua desse amor.
} 
É interessante, esse pensamento do filósofo Kierkegaard, pois assim como Santo Agostinho, ele acreditava que o amor cristão é baseado no relacionamento que o ser humano tem com Deus, que é o puro amor. Isso geraria preceitos que colocaria no indivíduo formas de cumprir para alcançar a divindade desse amor, logo o cumprimento de uma lei que, como Kierkegaard mencionou, onde haja sentimento íntegro, justo e concentrado, logo distingue-se todo aquele que possui o amor cristão. Ele ainda diz, em; As obras de Amor, (publicada em 1847):

Cristo era a Plenitude da lei. Dele devemos aprender como esta ideia deve ser compreendida, pois ele era a explicação, e sé quando a explicação é o que ela explica, quando aquele que explica é o explicado, quando a explicação é a transfiguração, só então a relação é a correta. Ai, dessa maneira não podemos nos explicar; pois se não podemos de outra maneira, nós podemos aprender a humildade na relação com Deus. Nossa vida terrena, que transcorre na fraqueza, tem de distinguir entre o explicar e o ser, e esta nossa fraqueza é uma expressão essencial para o modo como nos relacionamos com Deus. (KIERKEGAARD, 2005. p. 125).

Nisso, percebemos a lei como Deus sendo a plenitude para esse cumprimento. Diante do exposto o amor pode ser relacionado a Deus em Agostinho como o centro de toda a conclusão da vida humana, Ele é tido como o centro do mundo, do amor e logo da completa felicidade que o ser humano pode possuir. É inevitável ressaltar que a vida do homem o conduz a experiências que proporcionam prazer, ou seja, sentimento de satisfação, no entanto, essas são apenas alegrias parciais que transitam com a verdadeira felicidade absoluta que é estar na presença de Deus, como disse Agostinho em sua obra as Confissões.

É necessário termos o conhecimento de que todas as experiências vividas pelo homem tem que o dirigir a um espírito verdadeiro, logo, a um bem, pois é através de tais experiências que nos conscientizamos que 'o que não preenche não nos faz bem' (pois o vazio é ausência de bem). Para Santo Agostinho, o amor é a essência da substância divina. (Cf. AGOSTINHO, 1995, p. 33), ou seja, está presente em todos os homens através da entrega as coisas celestiais. Com isso, percebemos que é por meio desse direcionamento que o homem pode atingir a felicidade e repousar em Deus.

A partir do momento que o homem passa a amar verdadeiramente a Deus e como Ele ama, com gratuidade e fazendo o bem aos outros, sua vida será guiada corretamente aos verdadeiros caminhos, por isso, o ser e agir iluminado pela vontade do amor divino garante que a liberdade de ação seja justa, logo, ética. É o amor que conduz o homem a agir de forma coerente segundo a vontade de Deus e o desvia de agir somente por prazeres inconstantes. Conforme Agostinho ensina aos indivíduos, só vem existir realmente um coração livre quando o ser humano passa a viver na graça de Deus.

\subsection{O amor de Deus}


Quem é Deus? Essa foi uma pergunta feita por Santo Agostinho em seu livro as Confissões querendo conhecê-lo. Desde o nascimento, temos a convicção de que existiu em um tempo atrás um homem bom, correto, trazendo em seu coração o consolo, a verdade e que ensinava e pregava o amor às pessoas. Crescemos, alguns modificaram suas ideias e outros permaneceram na mesma visão: Existe um Deus.

Muitos ainda discutem sobre a existência e não existência de Deus, porém não se pode discutir sobre algo que é comprovado frequentemente através da vida, pois o inicio de tudo se deu a Sua criação perante nós, seres humanos. Deus emite um significado que vai além dos termos linguísticos, Ele paz, bondade, felicidade e a tradução de amor.

Agostinho, foi um dos filósofos mais entregues ao estudo sobre o Criador, percebemos isso em suas obras, como, Livre-arbitrio, Confissões, Solilóquios e A Vida Feliæ, entre outras, que o possibilitou destacarem a sua importância. Esse interesse não foi constante, mas veio depois da sua conversão, essa que lhe tirou do mundo dos pecados e o colocou frente com a verdadeira felicidade.

Agostinho ao indagar a pergunta, "Quem é Deus?" (AGOSTINHO, 1995, p. 213) ${ }^{1}$ procurou perguntar a todos os seres vivos se algum ali era Deus, depois de ouvir de todos," não sou eu, mas foi Ele que me criou", continuou á procurar resposta e a encontrou quando ouviu a voz da verdade interior que dizia:

"O teu Deus não é o céu, nem a terra, nem corpo algum". E a natureza deles exclama: "Repara que a matéria é menor na parte que no todo". Por isso te digo, ó minha alma, que és superior ao corpo, porque vivificas a matéria do teu corpo, dando-lhe vida, o que nenhum corpo pode fazer a outro corpo. Além disso, o teu Deus é também para ti vida da tua vida. (AGOSTINHO, 1995, p. 214)

Diante disso, percebemos que Agostinho via em Deus a essência Divina, uma fonte de vida para o ser humano onde o amor era constante e verdadeiro. Mas como ter a certeza desse amor?

O contexto do amor na filosofia em Santo Agostinho está ligado com o projeto de Deus para o homem, pois, para ele, o amor faz parte da essência do homem, sendo obra da criação Divina, logo classificando essa essência divina como amor. Porém, só a fé salva ou é necessário também às obras? Fé é a essência da verdade de Deus. (1Ts 2,13), Agostinho estabelecia em Deus o ser Celestial, cuja fé era o fundamento principal para alcançar a presença Dele. Ele diz em um de seus sermões: "Fé, entretanto, é acreditar no que você ainda não vê; para tal fé a recompensa é ver aquilo no que você acredita" (AGOSTINHO, 1995, p. 43), percebemos assim

\footnotetext{
1 Essa expressão “'Quem é Deus'? Perguntei-o á terra e disse-me: 'Eu não sou, mas foi Ele que me fez"' exemplifica no livro confissões mais um processo literário do Hiponense em interrogar os diversos seres sob diversos aspectos para um fim metafísico.
} 
que Agostinho estabelecia na fé a certeza de alcançar a graça de Deus. Desta forma, Agostinho via na fé a essência da salvação, pois quando se acredita em algo é nascido o fruto de uma esperança, logo a fé, logicamente as obras seriam apenas frutos dessa raiz da salvação.

O ser humano é uma obra do Criador, feito a sua imagem e semelhança (Gn 1.27). Como um pai não poderia amar seu filho? Somos arraigados a um laço constante com o Criador, mesmo que não sejamos perfeitos como Ele, somos 'pequenos' filhos, aprendendo com os nossos erros e falhas. Logo, o ser humano é também uma obra do amor.

O sentimento mais puro que possa existir é o amor, mas principalmente quando esse amor é um enlace fraternal, porque nós, seres humanos somos filhos do Criador. Consequentemente é essa classificação que destacamos para o amor de Deus, essa relação se dá pelo amor infinito de Deus para com seu filho (ser humano), como fala Agostinho, o amando com pureza e criando um relacionamento verdadeiro.

Agostinho vê em Deus o anelo que o mundo não pode oferecer, ele ressalta a seguinte mensagem referente ao livro de Salmos 17, 32. que diz:

\footnotetext{
Que sois, portanto, meu Deus? Que sois Vós, pergunto, senão o Senhor Deus? "E que outro Senhor há além do Senhor, ou que outro Deus além do nosso Deus?" Ó Deus tão alto, tão excelente, tão poderoso, tão onipotente, tão misericordioso e tão justo, tão oculto e tão presente, tão formoso e tão forte, estável e incompreensível, imutável e tudo mudando, nunca novo e nunca antigo, inovando tudo e cavando a ruína dos soberbos, sem que eles o advirtam; sempre em ação e sempre em repouso; granjeando sem precisão; conduzindo, enchendo e protegendo, criando, nutrindo e aperfeiçoando, buscando, ainda que nada Vos falte. (AGOSTINHO, 1995. p. 36)
}

Com isso, podemos notar que Deus é o ser supremo cheio de qualidades que o torna perfeito tanto como divindade como em obras. Assim, para o homem estar ligado a Ele pode ser classificado como cessamento de uma procura contínua. Agostinho via em Deus a esperança de uma vida eterna, ou seja, algo de verdade, essa possibilidade redigiu sua filosofia a uma meta onde Deus é quem estabelece o encontro de si na verdadeira felicidade. Assim, se ele fala que Deus é perfeito, se nele se encontra a liberdade, a felicidade, se nele está o bem, logo concluímos que Deus é o puro amor, pois sua infinita graça nos redige sempre aos caminhos melhores e assim temos a certeza do Seu eterno amor.

Porém, para Agostinho o ser humano só pode conhecer á Deus e entender esse imenso amor quando se afastar dos prazeres mundanos e se converte á uma vida fora das modéstias do mundo. Dessa forma passará a ter o anseio da presença D’ele que gera no homem o louvor e invocação a Deus pelo que Ele é e pelo Seu imenso amor. Em seu livro as Confissões, podemos perceber isso, ele pronuncia um texto da bíblia, livro de Salmos 95, 4.

És grande, Senhor e infinitamente digno de ser louvado; grande é teu poder, e incomensurável tua sabedoria. E o homem, pequena parte de tua criação quer louvar-te, 
e precisamente o homem que, revestido de sua mortalidade, traz em si o testemunho do pecado e a prova de que resistes aos soberbos. Todavia, o homem, partícula de tua criação, deseja louvar-te. Tu mesmo que incitas ao deleite no teu louvor, porque nos fizeste para ti, e nosso coração está inquieto enquanto não encontrar em ti descanso. (AGOSTINHO, 1995. pag. 34).

Notamos que Santo Agostinho tinha uma enorme fé e confiança em Deus. Podemos ressaltar que uma pessoa para estarem em estado de alegria precisa necessariamente ter um motivo, concluímos assim, que o motivo para o esplendor de Agostinho seria a intimidade que tinha alcançado em Deus e o conhecimento de sentir Seu amor todos os dias. A existência de Deus transporta um amor infinito, o amor que somente um pai pode ter com um filho, o cuidado, o carinho a proteção, amor esse que conduz o homem a está ligado totalmente Nele, pois Ele é a condição principal para que exista o amor. E para que possamos conhecer o amor de Deus temos que estar amando também as outras pessoas, pois como diz a bíblia, somos todos filhos do mesmo Criador.

\subsection{Amor ao próximo}

‘Amai uns aos outros, assim como Eu vós amo', João 13-34. O criador do universo que é o puro amor, nos deixa a seguinte lição: que amemos aos nossos semelhantes e aos nossos inimigos. Mas se é difícil amar ao próximo, como vamos amar o nosso inimigo? Diante desta questão, vamos esclarecer a relação desse amor na visão de Kierkegaard e Santo Agostinho.

O nascimento de Jesus prosseguiu em uma trajetória de ensinamentos, e Ele com toda Sua soberania e humildade nos deixou por escrito os mandamentos e lições a seguir. É interessante observarmos a concepção desse mandamento: ‘Amar ao próximo como a si mesmo', encontrada no livro de Marcos 12-31, a intensidade dele muda a trajetória de toda humanidade, pois este está na mesma linha que 'amarás o teu Deus acima de tudo'.

Santo Agostinho defendia a relação do amor ao próximo, além de achar que o amor de Deus seria a preferência em mandamento, mas, o certo também é a prática de amar seu semelhante, pois na prática, ele vem antes. Na obra, El concepto de amor, escrita por Hannah Arendt, Agostinho diz que a essência da lei nos manda amar os outros e isso determina a conduta do homem no mundo à medida que ele vai se constituindo, percebemos que Agostinho remete que para amar ao próximo devemos começar amando a Deus.

O amor cristão não procede do ser humano, mas requer que ele cumpra o mandamento do amor. Porém é lícito que diante de um mandamento aja a liberdade no indivíduo de cumpri-la ou rejeita-la, mas temos a noção que o amor é imperativo, mas é simultaneamente feito na forma de um chamado por um Deus que disponibiliza ao homem a possibilidade de escolher. O pensamento agostiniano enraíza no amor um princípio de socialização do indivíduo com a 
sociedade, ou seja, é uma inatividade que estabelece a libertação da espiritualidade, no qual, a miséria, e todos os sinônimos de pobreza são excluídos, e onde só habita o mesmo conceito de igualdade.

O amor ao próximo é a chave principal que liga o homem a Deus, pois a esse amor requer renúncia, desapego, ao qual fazendo isso, o homem passa a refazer sua ligação com a vontade do Criador, amando aos seus semelhantes sem distinção. Essa renúncia se torna parceira em abandonar a prática do mal e assim, permitiria a ação do amor, em que não seria apenas amar as nossas vontades, mas sim o próximo.

Esta renúncia a si exprime-se no comportamento face ao mundo. $\mathrm{O}$ mundo é amado enquanto criado; amando no mundo, a criatura ama o mundo como Deus. Esta aí a realização da renúncia a si que volta a dar a cada um no mundo, e também a si próprio, o seu sentido verdadeiro proveniente de Deus. Esta realização é o amor ao próximo. (ARENDT, 1997, p. 112).

Portanto, percebemos que para Santo Agostinho, o amor ao próximo consiste não no fato de todos estarem no mundo, mas sim, por ter sido criado pelo mesmo Deus. E logo, constatamos se todos foram criados por Deus o amor deve ser exalado a todas as pessoas sem distinção, pois como o nosso amigo-filósofo Kierkegaard diz: 'Pois quanto mais decidida e exclusivamente a predileção se liga a uma pessoa única, tanto mais longe está de amar ao próximo". (KIERKEGAARD, 2005, p. 83.).

Diante de pessoas tão diferentes, cheias de defeitos, pensamentos e maneiras se torna difícil amar ao próximo, imagine amar aos nossos inimigos. Qual a resposta para isso? Com isso entramos de uma forma mais detalhada na visão defendida pelo filósofo Kierkegaard a respeito do amor ao próximo.

Kierkegaard vê no amor o único sentimento do qual não se deve ou deveria abandonar, percebemos isso diante seu livro, As obras de Amor, em que discorre sobre a importância do assunto, sua perspectiva de amor também é baseada em 'pinceladas' de livros da bíblia, pois o mesmo era também era teólogo. Para o nosso filósofo, o amor ao próximo é distribuído a todo semelhante sem qualquer distinção, ou seja, devemos amar a todos e não só uma pessoa exclusivamente como foi citado mais acima.

Já ouvimos muito falar em ditados populares, como: 'Onde há ódio há amor', efetivamente essa lógica é contraditória, pois o ódio e o amor são coisas completamente diferentes. A questão de amar ao próximo, não visa para a condição financeira, raça, classe social, pensamentos diferentes, condutas desiguais ou desentendimentos, amar significa fazer o bem, exalar o sentimento mais puro que Deus plantou em nossos corações, já o ódio é um sentimento amargo, que destrói não só a pessoa odiada, mas a si mesmo. Afinal quem é o próximo? “Aquele 
que verdadeiramente ama o próximo, ama, portanto também, o seu inimigo [...] o próximo é a distinção completamente irreconhecível entre um homem e outro, ou é a eterna igualdade diante de Deus" (KIERKEGAARD, 2005, p. 89).

Logo, temos a resposta de Kierkegaard a respeito do ódio. Não adianta amar uma pessoa exclusivamente e achar que está seguindo o mandamento de Deus, no dicionário a palavra próximo, significa: Qualquer indivíduo que pode ser considerado como semelhante, assim, qualquer pessoa, seja da mais conhecida a aquela (o) que nunca vimos ou tivemos contato, serão todas pessoas a quem devemos amar verdadeiramente.

Esse amor ensinado por Deus, não significa aquele amor possuidor, de propriedade ou individual, como por exemplo, o casamento, o namoro. São status que requerem um amor exclusivamente ás suas pessoas que o formam, mas sim, fala do amor de humildade, respeito, caridade por nossos semelhantes, pois a partir do momento que exalamos com ternura o sentimento sincero dos nossos corações, estamos seguindo o mandamento de Deus e nos aproximando Dele. Sabemos que Deus não aprova a maldade, desprezo, arrogância, enfim, todos os sentimentos que classificam-se como maus, mas espera de nós o amor que nos ensinou desde a criação do mundo, provando seu imenso amor não só naquela época, mas todos os dias.

É interessante também esclarecermos o amor ao próximo ao amor humano e a amizade, pois Kierkegaard esclarece esse ponto em sua obra dizendo: "qualquer que seja a perda, ausência, desconsolo, o máximo ainda está por vir: ama o próximo!” (KIERKEGAARD, 2005. p. 85.). Se observarmos mais adiante ele explica que as perdas que temos, principalmente aquela de perder alguém próximo, como o amigo é doloroso, mas quando perdemos alguém somente com o título de semelhante, mesmo que esse faça algo contra ti, não se pode perdê-lo jamais, pois como ele diz:

É bem verdade, tu podes também continuar a amar o amado e o amigo, não importa o que eles façam para ti, mas não podes em verdade continuar a chamá-los de amado e amigo se eles, infelizmente, se tiverem modificado completamente. O próximo, ao contrário, nenhuma mudança pode roubá-lo de ti, pois não é o próximo que te segura, mas sim é o teu amor que segura o próximo; se o teu amor para com o próximo se mantiver inalterado, então o próximo permanecerá inalteradamente presente. (KIERKEGAARD, 2005, p. 86.).

Diante disso percebemos a importância do amor ao próximo na visão de Kierkegaard, Mesmo diante da perda de alguém exclusivamente perto, todo sentimento seria amenizado pelo amor a alguém que estaria próximo, pois continuaríamos a amar o amado, o amigo, mas o amor ao próximo não nos seguraria, ou seja, não nos prenderia a um ciclo, mas nos postaria a um sentimento inalterável, pois como diz o nosso filósofo mais acima é o nosso amor que assegura o próximo. 
Não, ama a pessoa amada fielmente e com ternura, mas deixa o amor ao próximo ser aquilo que santifica o pacto com Deus da união de vocês; ama teu amigo sinceramente e com dedicação, mas deixa o amor ao próximo ser aquilo que lhes ensina na amizade de um pelo outro a familiaridade com Deus! Vê que a morte abole todas as diferenças, mas a predileção se refere sempre a diferença: contudo, o caminho para a vida e para o eterno passa pela morte e pela abolição das diferenças: é por isso que só o amor ao próximo leva verdadeiramente a vida. (KIERKEGAARD, 2005. P. 83.).

O amor quando verdadeiro causa a edificação para alma. Mas o que é a edificação? Kierkegaard compara a edificação com o seguinte exemplo:

Dois homens, podem ter uma conduta a. Dois homens podem ter urna conduta diametralmente oposta; mas se cada um faz o contrário, no amor os opostos tornam-se edificantes. Não há na linguagem nenhuma palavra que seja em si e por si edificante, e não há nenhuma palavra na linguagem que não possa ser dita de modo edificante e não se torne edificante quando o amor está presente. (KIERKEGAARD, 2005, p. 244.).

O ser humano é dotado de conhecimentos, ações e espontaneidade, muitas vezes isso distorce o sentido verdadeiro das coisas, pois como preferimos 'os mais rasos do que o profundo', escolhemos os sentidos amplos e esquecemos que os verdadeiros significados são os mais importantes. Tomamos o exemplo da edificação, Kierkegaard esclarece que a edificação não no sentido amplo, mas no sentido linguístico correto é onde o amor está presente. A intensidade das palavras resultam no ser humano, com isso as expressões, ações, podem edificar um coração ou não. Se desejo o mal a alguém, logo estou desestimulando essa pessoa, porém, se expresso palavras sinceras de amor, estimulo o coração de qualquer individuo. Como nosso filósofo diz, "O amor edifica, ao pressupor que o próprio amor esteja presente. Desse modo, um que ama edifica o outro, e aqui é então bem fácil pressupô-lo, onde ele está notoriamente presente (KIERKEGAARD, 2005, p. 250.).

Com isso, notamos que a edificação é um pressupor do amor, pois só o amor edifica. Essa edificação significa portanto, erguer algo desde um fundamento, mas como Kierkegaard diz, [..] mas, espiritualmente, o amor é o fundamento de todas as coisas. (KIERKEGAARD, 2005. p. 255.). Implantar no coração do outro o fundamento do amor é algo distante da capacidade humana, porém o amor é o fundamento de todas as coisas, este é plantado nos corações humanos desde a criação pelo Criador, e assim, este amor brota diante das ações humanas perante a sua fé em Deus e perante o seu tratamento de amor com o próximo, pois só dessa forma o amor pode edificar a alma do ser humano.

Podemos considerar que tanto para Kierkegaard, como para Agostinho o amor era algo sublime que só poderia ser explicado se entendêssemos a divindade de Deus, pois Ele era o significado de amor. No livro de Coríntios podemos entender a extensão do amor, está escrito:

O amor é sofredor, é benigno; o amor não é invejoso; o amor não trata com leviandade, não se ensoberbece. Não se porta com indecência, não busca os seus 
interesses, não se irrita, não suspeita mal; Não folga com a injustiça, mas folga com a verdade; Tudo sofre, tudo crê, tudo espera, tudo suporta. $\mathrm{O}$ amor nunca falha; mas havendo profecias, serão aniquiladas; havendo línguas, cessarão; havendo ciência, desaparecerá; Porque, em parte, conhecemos, e em parte profetizamos; Mas, quando vier o que é perfeito, então o que o é em parte será aniquilado. (1 Coríntios 13:4-10).

Como diz acima, 'quando vier o que é perfeito, então o que é em parte profetizamos', ou seja, na linguagem agostiniana e kierkegaardiana, o amor é algo soberano que o indivíduo só poderia sentir verdadeiramente quando o sentimento brotado no seu coração fluísse com a presença do Criador, e essa soberanidade só alcançaria o grau supremo, quando estivesse em convicta intimidade com Deus. O amor ao próximo tanto para Santo Agostinho como para Kierkegaard é algo sublime enviado por Deus, implantado nos corações humanos, e que a prática do amor ao próximo é distribuída a qualquer pessoa, excluindo assim a expressão de ódio e gerando no entendimento humano que o mandamento, amar ao próximo como a si mesmo é a garantia de termos uma vida mais feliz e de relação com o Criador que é a fonte de todo o amor.

\section{Considerações Finais}

Desvendar as ideias humanas está em um termo inalcançável, pois suas principais características só são conhecidas pelo Criador, por isso que Ele está como centro de toda procura, anseio pelo homem, porque consideramos Deus como o principal motivo de tudo para os ciclos de nossas vidas. Logicamente, notamos que o amor e a liberdade são sentimentos que só serão sentidos na sua verdadeira essência, quando o homem estiver na graça divina do Criador. Santo Agostinho e Kierkegaard mostram isso nos seus pensamentos, pois mesmo diante de filosofias diferentes, estas se relacionam no mesmo sentido a respeito de que Deus é a chave para se encontrar o amor, sentir o amor e transmitir o amor. Assim, o homem estaria liberto dos seus sentimentos confusões, das suas inquietações e medos, pois quando se estivesse com Deus a Sua graça libertaria todo pecado, todo vazio e estaria preenchido pela verdadeira felicidade que só Deus pode oferecer.

\section{REFERÊNCIAS}

AgOSTINHO, A trindade. 2. ed. São Paulo: Paulus, 1995.

A graça e a liberdade. In: . A graça (II). Trad. de Agustinho Belmonte. São Paulo: Paulus, 1999. 
Confissões. São Paulo: Nova Cultural, 1999. Diálogo sobre a ordem. Lisboa: Imprensa Nacional, 2000.

O livre-arbítrio. 4. ed. São Paulo: Paulus, 2004.

ARENDT, Hannah. El concepto de amor en san Agustín, Madrid, Ed. Encuentro, 1997.

COUTO, Vinicius. Introdução à Teologia Armínio-Wesleyana. Reflexão, 2014.

KIERKEGAARD, S. Diário íntimo. Trad. María Angélica Bosco. Barcelona: Editorial Planeta, 1993.

O Conceito de Angústia. Trad. Álvaro L. M. Valls. Petrópolis: Vozes; São Paulo: Editora Universidade São Francisco, 2010.

As Obras do Amor. Petrópolis, RJ: Vozes, 2005.

SPROUL, R. Sola gratia: a controvérsia sobre o livre-arbítrio. Trad. Mauro Meister. São Paulo: Cultura Cristã, 2001. 